\title{
Cytotoxicity of Coprinopsis atramentaria extract, organic acids and their
}

synthesized methylated and glucuronate derivatives

Sandrina A. Heleno ${ }^{a, b}$, Isabel C.F.R. Ferreira ${ }^{\text {b, }}{ }^{,}$Ricardo C. Calhelha ${ }^{a, b}$, Ana P. Esteves ${ }^{a}$, Anabela Martins $^{\mathrm{b}}$, Maria João R.P. Queiroz ${ }^{\mathrm{a}}$

${ }^{a}$ Centro de Química, Universidade do Minho, Campus de Gualtar 4710-057 Braga, Portugal.

${ }^{b}$ Centro de Investigação de Montanha (CIMO), ESA, Instituto Politécnico de Bragança, Campus de Santa Apolónia, apartado 1172, 5301-855 Bragança, Portugal.

* Author to whom correspondence should be addressed (Isabel C.F.R. Ferreira; e-mail: iferreira@ipb.pt; telephone +351-273-303219; fax +351-273-325405). 


\begin{abstract}
Coprinopsis atramentaria is a wild edible mushroom whose methanolic extract revealed a marked antioxidant activity; $p$-hydroxybenzoic (HA), p-coumaric (CoA) and cinnamic (CA) acids were identified in the extract. In the present work, it was evaluated the cytotoxicity of $C$. atramentaria extract, previously identified organic acids and their synthesized derivatives (methylated compounds and protected glucuronides). Among all the tested cell lines (MCF-7- breast adenocarcinoma, NCI-H460- non-small cell lung carcinoma, HCT15- colon carcinoma, HeLa- cervical carcinoma and HepG2hepatocellular carcinoma), the extract presented good activity for the first three cell lines mentioned; in most of the cases methylated and glucuronide derivatives showed a higher activity than the corresponding parental compounds. The substitution of the carboxylic group (in parental organic acids) for an ester (in methylated derivatives) increased the cytotoxicity for tumor cell lines. Acetylated glucuronide derivatives showed higher cytotoxicity when compared with the corresponding parental acids.
\end{abstract}

Keywords: Coprinopsis atramentaria; Organic acids; Acetylated glucuronides; Methylated derivatives; Chemical synthesis; Cytotoxicity 


\section{Introduction}

Mushrooms consumption is increasing because of their unique and subtle flavor (Sadler, 2003), nutritional properties (Kalac, 2009) and richness on bioactive compounds. The scientific community, searching for new therapeutic alternatives, studied many different species and has found variable therapeutic activities such as anti-inflammatory and antibiotic effects (Lindquist, Niedermeyer, \& Jülich, 2005; Poucheret, Fons, \& Rapior, 2006; Alves et al., 2012; Heleno et al., 2013b). Moreover, mushrooms are a source of compounds with antitumor properties, including low-molecular-weight (e.g. quinones, sesquiterpenes, steroids) and high-molecular-weight (e.g. homo and heteropolysaccharides, glycoproteins) compounds (Ferreira, Vaz, Vasconcelos, \& Martins, 2010). Our attention is being focused on the capacity of organic acids (including phenolic acids) from mushrooms to inhibit the growth of different tumor cell lines.

Coprinopsis atramentaria (Bull.: Fr.) Redhead, Vilgalys \& Moncalvo, commonly known as the common ink cap or inky cap, is a widespread wild edible mushroom found in Europe and North America. Previously known as Coprinus atramentarius, it is the second best known ink cap and previous member of the genus Coprinus after Coprinus comatus. Clumps of mushrooms arise after rain from spring to autumn, commonly in urban and disturbed habitats such as vacant lots and lawns, as well as grassy areas. This mushroom, previously characterized by us for its nutritional composition showed a notable antioxidant activity; phenolic acids were identified in its extract (Heleno, Barros, Queiroz, Santos-Buelga, \& Ferreira, 2012) and have been reported as common compounds in mushrooms (Vaz et al., 2011).

Dietary phenolic compounds, including phenolic acids, are widely considered to contribute to health benefits in humans (Ho, Lee, \& Huang, 1992). Nevertheless, there 
are very few studies dealing with cytotoxicity of phenolic acids and related compounds. Cinnamic and protocatechuic acids revealed cytotoxicity for a lung cancer cell line, and were implied in the capacity of Clitocybe alexandri to induce cell cycle arrest and apoptosis in the same cell line (Vaz, Almeida, Ferreira, Martins, \& Vasconcelos, 2012). Cinnamic acid was also pointed out as possessing antitumor activity against human malignant tumors, including melanoma, glioblastoma, adenocarcinoma of the prostate and lung (Liu, Hudgins, Shack, Yin, \& Samid, 1995) and colon adenocarcinoma (Ekmekcioglu et al., 1998). Drupanin and baccharin, two cinnamic acid derivatives, were reported as inhibitors of the growth of HeLa-60 cell lines by inducing apoptosis (Akao et al., 2003).

However, little is known about phenolic acids bioactive forms in vivo and the mechanisms by which they may contribute toward disease prevention. In fact, many studies have ignored the question of their metabolism (Scalbert \& Williamson, 2000; Rechner et al., 2002; Manach, Williamson, Morand, Scalbert, \& Remesy, 2005; Nardini et al., 2009). After absorption from the gastrointestinal tract, these molecules circulate in human plasma as conjugated forms namely glucuronide and methylated derivatives (Rechner et al., 2002; Piazzon et al., 2012).

As far as we know, nothing has been reported on cytotoxicity of $C$. atramentaria extract and glucuronide or methylated derivatives of phenolic acids. Detailed knowledge concerning the conjugative and metabolic events following the ingestion of these organic acids is crucial to the understanding of their bioactivity effect, in order to clarify the role of the metabolites in the pharmacology of the parental substance. Therefore, in the present work, it was evaluated the cytotoxicity of $C$. atramentaria extract, organic acids ( $p$-hydroxybenzoic, $p$-coumaric and cinnamic acids) and their synthesized derivatives: methylated derivatives and protected glucuronides. 


\section{Materials and methods}

\subsection{Wild mushroom and preparation of the extract}

Samples of Coprinopsis atramentaria (Bull.: Fr.) Redhead, Vilgalys \& Moncalvo were collected in Bragança (Northeast Portugal). After taxonomic identification of the sporocarps (Oria de Rueda, 2007), specimens were deposited at the herbarium of School of Agriculture of Polytechnic Institute of Bragança. The samples were lyophilized (FreeZone 4.5 model 7750031, Labconco, Kansas, USA), reduced to a fine powder (20 mesh) and kept at room temperature inside a desiccator until further analysis (within a week).

The powder $(\sim 10 \mathrm{~g})$ was extracted with methanol $(250 \mathrm{ml})$ at $-20{ }^{\circ} \mathrm{C}$ for $6 \mathrm{~h}$. The extract was sonificated for $15 \mathrm{~min}$, centrifuged at $4000 \mathrm{~g}$ for $10 \mathrm{~min}$ and filtered through Whatman No.4 paper. The residue was then re-extracted with three additional $150 \mathrm{ml}$ portions of methanol. The combined extracts were evaporated (rotary evaporator Büchi R-210; Flawil, Switzerland) at $40{ }^{\circ} \mathrm{C}$ to dryness.

\subsection{Organic acids}

p-Hydroxybenzoic acid (HA), p-coumaric acid (CoA) and cinnamic acid (CA) were identified in C. atramentaria extract (Heleno et al., 2012). For cytotoxicity assays, these compounds were purchased from Sigma (St. Louis, MO, USA; CAS numbers 99-96-7, 501-98-4 and 140-10-3, respectively).

2.3. Acetylated glucuronide derivatives (protected forms of $\mathrm{p}$-coumaric, $\mathrm{p}$ hydroxybenzoic and cinnamic acid glucuronides) 
2.3.1. Synthesis of 2,3,4-tri-O-acetyl-1-p-coumaroyl-D-glucuronic acid methyl ester $(C o A G P)$.

p-Coumaric acid $(0.100 \mathrm{~g}, 0.609 \mathrm{mM})$, acetobromo- $\alpha$-D-glucuronic acid methyl ester $(0.362 \mathrm{~g}, 0.914 \mathrm{mM})$ and potassium carbonate $(0.084 \mathrm{~g}, 0.609 \mathrm{mM})$ were dissolved in $10 \mathrm{ml}$ of DMSO under argon and the mixture was stirred for $24 \mathrm{~h}$. The reaction mixture was diluted with $50 \mathrm{ml}$ of ethyl acetate and then washed with water $(7 \times 10 \mathrm{ml})$. The organic layer was dried over $\mathrm{MgSO}_{4}$ and the solvent was evaporated. The product obtained was purified by a column chromatography using silica gel 60A (60-200 micron) and a mixture of ethyl acetate/petroleum ether $(55 / 45, \mathrm{v} / \mathrm{v})$ as eluent. The product was then crystallized with acetone and was isolated as a white solid $(0.095 \mathrm{~g}$, 33\%). M.p. $=201-202^{\circ} \mathrm{C}{ }^{1} \mathrm{H}$ NMR $\left(300 \mathrm{MHz}, \mathrm{CDCl}_{3}\right): \delta=2.03(\mathrm{~s}, 3 \mathrm{H}), 2.06(\mathrm{~s}, 3 \mathrm{H})$, $2.07(\mathrm{~s}, 3 \mathrm{H}), 3.75(\mathrm{~s}, 3 \mathrm{H}), 4.25(\mathrm{~d}, J=9.3 \mathrm{~Hz}, 1 \mathrm{H}), 5.27$ (ap t, $J=9.3$ and $8.1 \mathrm{~Hz}, 1 \mathrm{H})$, $5.28(\mathrm{t}, J=9.3 \mathrm{~Hz}, 1 \mathrm{H}), 5.38(\mathrm{t}, J=9.3 \mathrm{~Hz}, 1 \mathrm{H}), 5.90(\mathrm{~d}, J=8.1 \mathrm{~Hz}, 1 \mathrm{H}), 6.14(\mathrm{~d}, J=16$ $\mathrm{Hz}, 1 \mathrm{H}), 6.84(\mathrm{~d}, J=8.7 \mathrm{~Hz}, 2 \mathrm{H}), 7.38(\mathrm{~d}, J=8.7 \mathrm{~Hz}, 2 \mathrm{H}), 7.61(\mathrm{~d}, J=16 \mathrm{~Hz}, 1 \mathrm{H}){ }^{(*)} \cdot{ }^{13} \mathrm{C}$ NMR (75.4 MHz, $\left.\mathrm{CDCl}_{3}\right): 20.48\left(\mathrm{CH}_{3}\right), 20.56\left(\mathrm{CH}_{3}\right), 20.58\left(\mathrm{CH}_{3}\right), 53.15\left(\mathrm{OCH}_{3}\right)$, $69.08(\mathrm{CH}), 70.13(\mathrm{CH}), 71.81(\mathrm{CH}), 72.84(\mathrm{CH}), 91.35(\mathrm{CH}), 112.85(\mathrm{CH}), 115.97$ $(2 \times \mathrm{CH}), 126.33(\mathrm{C}), 130.47(2 \times \mathrm{CH}), 147.39(\mathrm{CH}), 158.69(\mathrm{C}), 164.91(\mathrm{C}=\mathrm{O}), 167.26$ $(\mathrm{C}=\mathrm{O}), 169.45(\mathrm{C}=\mathrm{O}), 169.55(\mathrm{C}=\mathrm{O}), 169.96 \quad(\mathrm{C}=\mathrm{O})$. HRMS (ESI) calcd. for $\mathrm{C}_{22} \mathrm{H}_{24} \mathrm{NaO}_{12}\left(\mathrm{M}^{+}+\mathrm{Na}\right)$ 503.1160, found 503.1164.

${ }^{(*)}$ The proton of the $\mathrm{OH}$ group was not detected in the proton NMR spectrum.

2,3,4-tri- $O$-acetyl-1-p-hydroxybenzoyl-D-glucuronic acid methyl ester $(H A G P)$ and 2,3,4-tri-O-acetyl-1-cinnamoyl-D-glucuronic acid methyl ester $(C A G P)$ were obtained according to the procedure described by Heleno et al. (2013a). 
2.4.1. Synthesis of methyl 3-(4-hydroxyphenyl)acrylate (CoAM1), methyl 4hydroxybenzoate (HAM1) and methyl 3-phenylacrylate (CAM)

p-Coumaric (CoA), p-hydroxybenzoic (HA) and cinnamic (CA) acids (0.100 g) were stirred at room temperature with $7.5 \mathrm{ml}$ of methanol, containing $0.2 \mathrm{ml}$ of concentrated $\mathrm{H}_{2} \mathrm{SO}_{4}$ for 5 days (Reis et al., 2010). The solvent was then partially evaporated under reduced pressure, and the solution was neutralized with aqueous $1 \mathrm{M} \mathrm{Na}_{2} \mathrm{CO}_{3}$. The mixture was extracted with diethyl ether $(3 \times 15 \mathrm{ml})$. The organic phases were combined, washed with water $(3 \times 10 \mathrm{ml})$, dried over $\mathrm{MgSO}_{4}$, and the solvent was evaporated.

The products: CoAM1, HAM1 and CAM were isolated as yellow solids $(0.080 \mathrm{~g}, 74 \%$; 0.075 g, 68\%; 0.083 g, 75\%, respectively). CoAM1 M.p. $=120-122^{\circ} \mathrm{C}{ }^{1} \mathrm{H}$ NMR (400 MHz, DMSO- $\left.d_{6}\right): \delta=3.68(\mathrm{~s}, 3 \mathrm{H}), 6.38(\mathrm{~d}, J=16 \mathrm{~Hz}, 1 \mathrm{H}), 6.78(\mathrm{~d}, J=8.8 \mathrm{~Hz}, 2 \mathrm{H}), 7.54$ $(\mathrm{d}, J=8.8 \mathrm{~Hz}, 2 \mathrm{H}), 7.55(\mathrm{~d}, J=16 \mathrm{~Hz}, 1 \mathrm{H}), 9.99(\mathrm{OH}) .{ }^{13} \mathrm{C}$ NMR $(75.4 \mathrm{MHz}$, DMSO$\left.d_{6}\right): 51.19\left(\mathrm{OCH}_{3}\right), 113.89(\mathrm{CH}), 115.73(2 \times C H), 125.04(\mathrm{C}), 130.28(2 \times C H), 144.72$ $(\mathrm{CH}), 159.82(\mathrm{C}), 167.02(\mathrm{C}=\mathrm{O})$. HRMS (EI-TOF) calcd. for $\mathrm{C}_{10} \mathrm{H}_{10} \mathrm{O}_{3}\left(\mathrm{M}^{+}\right)$178.0630, found 178.0630 .

HAM1 and CAM are known and commercially available reagents (Sigma, St. Louis, MO, USA; CAS numbers 99-76-3 and 103-26-4, respectively). Mp are in agreement with the ones reported by Sigma Aldrich $\mathrm{HAM} 1=128-130^{\circ} \mathrm{C}, \mathrm{CAM}=44-46^{\circ} \mathrm{C}$.

\subsubsection{Synthesis of methyl 3-(4-methoxyphenyl)acrylate (CoAM2) and methyl p-anisate} (HAM2)

$p$-Coumaric and $p$-hydroxybenzoic acids $(0.300 \mathrm{~g})$, dimethyl sulphate (1 equiv.) and potassium carbonate (2 equivs) were stirred with acetone $(50 \mathrm{ml})$ at $45-50^{\circ} \mathrm{C}$ for $24 \mathrm{~h}$ (Deng et al., 2006). The solvent was evaporated. The residue was suspended in an ammonia solution $(3.6 \% \mathrm{w} / \mathrm{v} ; 7 \mathrm{ml})$ and extracted with ethyl acetate $(3 \times 3 \mathrm{ml})$. The 
combined ethyl acetate extracts were dried over $\mathrm{MgSO}_{4}$, and the solvent was evaporated. The products CoAM2 and HAM2 were isolated as white solids, $(0.213 \mathrm{~g}, 61 \% ; 0.224 \mathrm{~g}$, 62\%). CoAM2 M.p. $=87-89^{\circ} \mathrm{C}{ }^{1} \mathrm{H}$ NMR $\left(300 \mathrm{MHz}, \mathrm{CDCl}_{3}\right): \delta=3.80(\mathrm{~s}, 3 \mathrm{H}), 3.85(\mathrm{~s}$, $3 \mathrm{H}), 6.32(\mathrm{~d}, J=15.9 \mathrm{~Hz}, 1 \mathrm{H}), 6.91(\mathrm{~d}, J=8.7 \mathrm{~Hz}, 2 \mathrm{H}), 7.48(\mathrm{~d}, J=9.0 \mathrm{~Hz}, 2 \mathrm{H}), 7.66(\mathrm{~d}$,

$J=15.9 \mathrm{~Hz}, 1 \mathrm{H}) .{ }^{13} \mathrm{C}$ NMR (75.4 MHz, CDCl3): $51.57\left(\mathrm{OCH}_{3}\right), 55.36\left(\mathrm{OCH}_{3}\right), 114.30$ $(2 \times C H), 115.24(\mathrm{CH}), 127.10(\mathrm{C}), 129.71(2 \times C H), 144.52(\mathrm{CH}), 161.37(\mathrm{C}), 167.77$ $(\mathrm{C}=\mathrm{O})$. HRMS (EI-TOF) calcd. for $\mathrm{C}_{11} \mathrm{H}_{12} \mathrm{O}_{3}\left(\mathrm{M}^{+}\right)$192.0786, found 192.0790.

HAM2 is a known and commercially available reagent (Sigma, St. Louis, MO, USA; CAS number 121-98-2). Mp are in agreement with the one reported by Sigma Aldrich $\mathrm{HAM} 2=52-54^{\circ} \mathrm{C}$.

2.4.3. Synthesis of 3-(4-methoxyphenyl)acrylic acid (CoAM3) and 4-methoxybenzoic acid (HAM3)

Methyl 3-(4-methoxyphenyl)acrylate (CoAM2) and methyl p-anisate (HAM2) (0.100 g), $\mathrm{NaOH}$ ( 3 equivs) were stirred in ethanol at $65^{\circ} \mathrm{C}$ for $3 \mathrm{~h}$. The solvent was evaporated. The residue was dissolved in water and adjusted to $\mathrm{pH}=3$ with a solution of $\mathrm{HCl} 37 \%$. The residues was then filtered and the products CoAM3 and HAM3 were isolated as white solids ( $0.050 \mathrm{~g}, 54 \%$ and $0.074 \mathrm{~g}, 80 \%$, respectively).

CoAM3 and HAM3 are known and commercially available reagents (Sigma, St. Louis, MO, USA; CAS numbers 830-09-1 and 100-09-4, respectively). Mps are in agreement with the ones reported by sigma Aldrich. CoAM3 $=175-177^{\circ} \mathrm{C}, \mathrm{HAM} 3=185-187^{\circ} \mathrm{C}$.

\subsection{Cytotoxicity assays}

Five human tumor cell lines were used: MCF-7 (breast adenocarcinoma) from DSMZ (Leibniz-Institut DSMZ - Deutsche Sammlung von Mikroorganismen und Zellkulturen 
GmbH), NCI-H460 (non-small cell lung carcinoma), HCT15 (colon carcinoma), HeLa (cervical carcinoma) and HepG2 (hepatocellular carcinoma) from ECACC (European Collection of Cell Cultures). Cells were routinely maintained as adherent cell cultures at $37{ }^{\circ} \mathrm{C}$, in a humidified air incubator containing $5 \% \mathrm{CO}_{2}$. Cells were cultured in: i) RPMI-1640 medium supplemented with10\% heat-inactivated fetal bovine serum (FBS) and $2 \mathrm{mM}$ glutamine, for the MCF-7, NCI-H460 and HCT15 cell lines and ii) DMEM supplemented with $10 \%$ FBS, $2 \mathrm{mM}$ glutamine, $100 \mathrm{U} / \mathrm{ml}$ penicillin and $100 \mathrm{mg} / \mathrm{ml}$ streptomycin, for HeLa and HepG2 cells. To assess the cytotoxicity of the extract/compounds, the Sulforhodamine B assay was performed according to a procedure previously described by the authors (Abreu et al., 2011). For this, each cell line was plated at an appropriate density $\left(7.5 \times 10^{3}\right.$ cells/well for MCF-7, NCI-H460 and HCT15 cells or $1.0 \times 10^{4}$ cells/well for HeLa and HepG2 cells) in 96-well plates.

For the evaluation of toxicity towards liver cells, a primary cell culture was prepared from a freshly harvested porcine liver obtained from a local slaughter house, according to a procedure previously established by some of us (Abreu et al., 2011), these cells were designated as PLP2 cells. Cell culture was continued with direct monitoring every two to three days using a phase contrast microscope. Before confluence was reached, cells were sub-cultured and plated in 96-well plates at a density of $1.0 \times 10^{4}$ cells $/$ well, and cultured in DMEM medium with $10 \%$ FBS, $100 \mathrm{U} / \mathrm{ml}$ penicillin and $100 \mu \mathrm{g} / \mathrm{ml}$ streptomycin.

Cells were treated for $48 \mathrm{~h}$ with the different extract/compound solutions (the extract was dissolved in water at $8 \mathrm{mg} / \mathrm{ml}$; methylated and glucuronide compounds were dissolved in DMSO at $100 \mathrm{mM}$ and $40 \mathrm{mM}$, respectively) and the procedure for SRB assay was followed, as described above. The results were expressed in $\mathrm{GI}_{50}$ values 
(concentrations that inhibited $50 \%$ of the net cell growth). Ellipticine was used as positive control.

\subsection{Statistical analysis}

One-way analysis of variance (ANOVA) was performed followed by Tukey's honestly significant difference post hoc test with $\alpha=0.05$, coupled with Welch's statistic. This treatment was carried out using SPSS v. 18.0 program.

\section{Results and Discussion}

\subsection{Synthesis of acetylated glucuronide and methylated derivatives}

$p$-Coumaric acid (CoA) was reacted with acetobromo- $\alpha$-D-glucuronic acid methyl ester (1.5 equiv.) according to the procedure described by our group (Heleno et al., 2013a), affording the corresponding 2,3,4-tri-O-acetyl-1-p-coumaroyl-D-glucuronic acid methyl ester (CoAGP, Scheme 1), with 33\% yield after purification, which is in agreement with the yields previously reported for $H A G P$ and $C A G P(38 \%$ and $32 \%$, respectively; Heleno et al., 2013a). As far as we know, this is the first report on the synthesis of protected glucuronide derivatives of CoA. Nevertheless, there are studies describing the synthesis of protected glucuronide derivatives of $p$-hydroxybenzoic (HA) and cinnamic (CA) acids (HAGP and $C A G P$; Heleno et al., 2013a), ferulic acid (25\% yield; Piazzon et al., 2012) and of ethyl-4-hydroxybenzoate (Zhang et al., 2012). The yields obtained in the chemical synthesis of these compounds are considered good, since the in vivo glucuronidation that occur in animal metabolism involve specific enzymes.

CoA, HA and CA were reacted with methanol and sulphuric acid according to the procedure described by Reis et al. (2010), to afford the corresponding CoAM1, HAM1 and $C A M$ in good yields $(74 \%, 68 \%$ and $75 \%$, respectively). An esterification reaction 
was carried out in order to prepare the carboxylic ester derivatives, the para-hydroxyl groups were unreacted under these conditions for HAM1 and COAM1. These methylated compounds are common metabolites obtained in vivo from organic acids. HAMI and $C A M$ are commercially available compounds, but our group synthesized them to perform the biological assays. Otherwise, as far as we know, CoAMl is a new compound, being fully characterized herein.

CoA and HA were reacted with dimethyl sulphate (1 equiv.) and potassium carbonate (2 equiv.) (Deng et al., 2006) to give CoAM2 and HAM2 in good yields $(61 \%$ and $62 \%$ respectively), affording in both cases dimethylated derivatives. These compounds are possible methylated metabolites also circulating in the organism; HAM2 is a commercially available reagent, while COAM2 is a new compound fully characterized herein.

CoAM2 and HAM2 were reacted with $\mathrm{NaOH}$ (3 equiv.) in ethanol to perform a regioselective hydrolysis of the ester group affording COAM3 and HAM3 in moderate to good yields (54\% and $80 \%$, respectively), with a free carboxylic group. Despite CoAM3 and HAM3 are commercially available compounds, they were synthesized in order to complete the series of methylated metabolites and compare the bioactivity of the different possible methylations of each parental organic acid.

\subsection{Cytotoxicity of C. atramentaria extract}

C. atramentaria extract showed high cytotoxicity for MCF-7, NCI-H460 and HCT15 cell lines (Table 1). Furthermore, it did not show any activity against liver primary cells $\left(\mathrm{GI}_{50}>400 \mu \mathrm{g} / \mathrm{ml}\right)$. The obtained values are relevant in comparison with other reports on cytotoxicity of mushroom extracts for tumor cell lines. Vaz et al. (2010) reported the following $\mathrm{GI}_{50}$ values of Clitocibe alexandri ethanolic extract: $24.8 \pm 2.3 \mu \mathrm{g} / \mathrm{ml}$ (NCI- 
H460), 17.9 $\pm 1.3 \mu \mathrm{g} / \mathrm{ml}$ (MCF7), $21.7 \pm 2.3 \mu \mathrm{g} / \mathrm{ml}(\mathrm{HCT}-15)$ and $26.0 \pm 1.3 \mu \mathrm{g} / \mathrm{ml}$ (AGS, gastric cancer). The same authors described $\mathrm{GI}_{50}$ values of Suillus collinitus methanolic extract of $62.5 \pm 6.3 \mu \mathrm{g} / \mathrm{ml}, 25.2 \pm 0.16 \mu \mathrm{g} / \mathrm{ml}, 103.2 \pm 9.9 \mu \mathrm{g} / \mathrm{ml}$ and $79.2 \pm 15.5 \mu \mathrm{g} / \mathrm{ml}$, respectively for each of the previous mentioned cell lines (Vaz et al., 2012b).

It should be highlighted that the $C$. atramentaria methanolic extract showed higher activity than individual compounds. This can be due to additive and synergistic effects of compounds such as $p$-hydroxybenzoic ( $4.71 \mathrm{mg} / 100 \mathrm{~g}$ dry weight), $p$-coumaric $(0.82$ $\mathrm{mg} / 100 \mathrm{~g})$ and cinnamic $(1.70 \mathrm{mg} / 100 \mathrm{~g})$ acids previously identified in the extract (Heleno et al., 2012). Besides the organic acids previously mentioned, C. atramentarius is well known to produce coprine, a cyclopropyl amino acid that generates a metabolite, which inhibits alcohol dehydrogenase and, therefore, it cannot be simultaneously consumed with alcohol. All these compounds could be responsible for the cytotoxicity showed by the extract. Regarding the other cell lines, HeLa and HepG2, the extract did not show activity at the highest tested concentration $(400 \mu \mathrm{g} / \mathrm{ml})$, which indicates that the compounds present in the extract are not active for these cell lines, or that antagonist effects could occur.

\subsection{Cytotoxicity of p-coumaric acid and derivatives}

p-Coumaric acid (CoA) revealed very weak cytotoxicity for three cell lines, and no activity for $\mathrm{HeLa}$ and $\mathrm{HePG}_{2}$ cells. Nevertheless, the activity of its glucuronide derivative (CoAGP) was moderate for all the tumor cell lines, being more active against $\mathrm{HePG}_{2}$ cells (Table 1). The methylated derivatives CoAM1 and CoAM2 also presented moderate activity against all the tested tumor cell lines. This could be attributed to the presence of ester groups; in both compounds the carboxylic group of the parental molecule was replaced by an ester; CoAM1 has a hydroxyl group in the para position, 
while CoAM2 presents a methoxyl group in the same position. However, CoAM3 that remains the carboxylic group of CoA but with a methoxyl group in the para position showed a very weak activity.

\subsection{Cytotoxicity of p-hydroxybenzoic acid and derivatives}

p-Hydroxybenzoic acid (HA) did not show activity against none of the tumor cell lines (Table 1). This in in agreement with Vaz et al. (2012a) that also reported the lack of activity of HA against NCI-H460 cells at the highest tested concentration (3000 $\mu \mathrm{M})$. Nonetheless, its glucuronide derivative, HAGP, gave a moderate activity against the tested cell lines, with the exception of HePG2 cells in which this compound revealed a good activity. The methylated derivatives, HAM1 and HAM2 showed very weak activity, with the exception of HAM1 for HeLa cells that presented a moderate activity; HAM3 had no activity. Once more, the presence of an ester group increased the growth inhibitory activity of the compounds; HAM1 has the carboxylic group replaced by an ester group and a hydroxyl group in the para position, while HAM2 has also a carboxylic group replaced by an ester group and a methoxy group in the para position. HAM3 that remains with the carboxylic group, revealed no activity.

\subsection{Cytotoxicity of cinnamic acid and derivatives}

Cinnamic acid (CA) has also a weak activity against NCI-H460, HCT15 and HeLa cell lines, and no activity for the other cell lines (Table 1). Vaz et al. (2012a) reported a $\mathrm{GI}_{50}$ value of cinnamic acid for NCI-H460 cells $(845.9 \pm 97.5 \mu \mathrm{M})$ similar to the one described herein. Otherwise, Ekmekcioglu et al. (1998) reported that CA has antiproliferative effects against colon cancer cells with a maximal effect at $8.0 \mathrm{mM}$ with $\mathrm{GI}_{50}$ values between $4.0-5.0 \mathrm{mM}$. The glucuronide derivative (CAGP) revealed a 
moderate activity against all the cell lines. The methylated derivative presented low activity for HCT15 cell line and no activity for the other tested cell lines.

CAM has also the carboxylic group replaced by an ester and has no groups in para position. In this case the presence of the ester group did not increased the activity.

It should be highlighted that despite the high $\mathrm{GI}_{50}$ values obtained for the individual compounds (much higher than the values for ellipticine), they did not present any toxicity for non-tumor cells PLP2; meaning that we could increase the therapeutic doses without toxicity effects. This is very important regarding the high toxicity revealed by the positive control/antitumor compound (in which the range between therapeutic and toxic doses is very short).

Overall, the extract showed higher activity than individual compounds, maybe due to synergistic effects among the present molecules. This study allowed a comparison between parental molecules and derived metabolites; it is important to understand the behavior of organic acids (including phenolic acids) regarding their bioactivity after metabolism, and this study, gives clues on this matter. Organic acids are extensively metabolized in humans, being methylation and glucuronation two of the conjugated forms occurring in the organism and giving methylated and glucuronide metabolites, respectively. In this work, it was proved that the substitution of the carboxylic group (in parental organic acids) for an ester (in methylated derivatives) increased the cytotoxicity of the parental compounds. The acetylated glucuronide derivatives had considerably increase the cytotoxicity when compared with the respectively parental compounds.

Although future studies should be carried out in order to clarify specific mechanistic pathways, the present study contributes to compare the bioactivity of organic acids and derivative compounds, including possible human metabolites. 


\section{Acknowledgements}

The authors are grateful to Fundação para a Ciência e a Tecnologia (FCT, Portugal) for financial support to the Portuguese NMR network and to FCT and FEDERCOMPETE/QREN/EU for the financial support through the research project PTDC/AGR-ALI/110062/2009 and the research centres (PEst-C/QUI/UI0686/2011 and PEst-OE/AGR/UI0690/2011). S.A. Heleno (BD/70304/2010) and R.C. Calhelha (BPD/68344/2010) also thank FCT, POPH-QREN and FSE.

\section{References}

Abreu, R.M.V., Ferreira, I.C.F.R., Calhelha, R.C., Lima, R.T., Vasconcelos, M.H., Adega, F., Chaves, R. \& Queiroz, M.-J.R.P. (2011). Anti-hepatocellular carcinoma activity using human HepG2 cells and hepatotoxicity of 6substituted methyl 3-aminothieno[3,2-b]pyridine-2-carboxylate derivatives: In vitro evaluation, cell cycle analysis and QSAR studies. European Journal of Medicinal Chemistry, 46, 5800-5806.

Akao, Y., Maruyama, H., Matsumoto, K., Ohguchi, K., Nishizawa, K., Sakamoto, T., Araki, Y., Mishima, S., \& Nozawa, Y. (2003). Cell growth inhibitory effect of cinnamic acid derivatives from propolis on human tumor cell lines. Biological and Pharmaceutical Bulletin, 26, 1057-1059.

Alves, M.J., Ferreira, I.C.F.R., Dias, J., Teixeira, V., Martins, A., \& Pintado, M. (2012). A review on antimicrobial activity of mushroom (Basidiomycetes) extracts and isolated compounds. Planta Medica, 78, 1707-1718.

Deng, D., Zhang, J., Cooney, J.M., Skinner, M.A., Adain, A., Jensen, D.J., \& Stevenson, D.E. (2006). Methylated polyphenols are poor "chemical" 
antioxidants but can still effectively protect cells from hydrogen peroxideinduced cytotoxicity. FEBS Letters, 580, 5247-5250.

Ekmekcioglu, C., Feyertag, J., \& Marktl, W. (1998). Cinnamic acid inhibits proliferation and modulates brush border membrane enzyme activities in Caco2 cells. Cancer Letters, 128, 137-144.

Ferreira, I.C.F.R., Vaz, J.A., Vasconcelos, M.H., \& Martins, A. (2010). Compounds from Wild Mushrooms with Antitumor Potential. Anti-Cancer Agents in Medicinal Chemistry, 10, 424-436.

Heleno, S.A., Ferreira, I.C.F.R., Esteves, A.P., Ciric, A., Glamoclija, J., Martins, A., Sokovic, M., \& Queiroz, M.-J.R.P. (2013a). Antimicrobial and demelanizing activity of Ganoderma lucidum extract, p-hydroxybenzoic and cinnamic acids and their synthetic acetylated glucuronide methyl esters. Food and Chemical Toxicology, 58, 95-100.

Heleno, S.A., Stojković, D., Barros, L., Glamočlija, J., Soković, M., Martins, A., Queiroz, M.J.R.P., \& Ferreira, I.C.F.R. (2013). A comparative study of chemical composition, antioxidant and antimicrobial properties of Morchella esculenta (L.) Pers. from Portugal and Serbia. Food Research International, 51, 236-243.

Heleno, S.A., Barros, L., Queiroz, M.-J.R.P., Santos-Buelga, C., \& Ferreira, I.C.F.R. (2012). Phenolic, polysaccharidic and lipidic fractions of mushrooms from northeast Portugal: chemical compounds with antioxidant properties. Journal of Agricultural and Food Chemistry, 60, 4634-4640.

Ho, C. T., Lee, C. V., \& Huang, M. T., eds. (1992). Phenolic compounds in food and their effects in health I+II. Washington, DC: American Chemical Society.

Kalač, P. (2009). Chemical composition and nutritional value of European species of wild growing mushrooms: A review. Food Chemistry, 113, 9-16. 
Liu, L., Hudgins, W.R., Shack, S., Yin, M.Q., \& Samid, D. (1995). Cinnamic acid: a natural product with potential use in cancer intervention. International Journal of Cancer, 62, 345-350.

Lindequist, U., Niedermeyer, T.H.J., \& Jülich, W.-D. (2005). The pharmacological potential of mushrooms. eCAM, 2, 285-299.

Manach, C., Williamson, G., Morand, C., Scalbert, A., \& Remesy, C. (2005). Bioavailability and bioefficacy of polyphenols in humans. I. Review of 97 bioavalability studies. American Journal of Clinical Nutrition, 81, 230S-242S.

Nardini, M., Forte, M., Vrhovsek, U., Mattivi, F., Viola, R., \& Scaccini, C. (2009). White wine phenolics are absorbed and extensively metabolized in humans. Journal of Agricultural and Food Chemistry, 57, 2711-2718.

Oria de Rueda, J.A. (2007). Hongos y setas. Tesoro de nuestros montes. Palencia, Spain: Ediciones Cálamo.

Piazzon A., Vrhovsek, U., Masuero, D., Mattivi, F., Mandoj, F., \& Nardini, M. (2012). Antioxidant activity of phenolic acids and their metabolites: Synthesis and antioxidant properties of the sulphate derivatives of ferulic and caffeic acids and of the acyl glucuronide of ferulic acid. Journal of Agricultural and Food Chemistry, $60,12312-12323$.

Poucheret, P., Fons, F., \& Rapior, S. (2006). Biological and pharmacological activity of higher fungi: 20-Year retrospective analysis. Mycologie, 27, 311-333.

Rechner, A. R., Kuhnle, G., Bremner, P., Hubbard, G. P., Moore, K. P., \& Rice-Evans, C. A. (2002). The metablic fate of dietary polyphenols in humans. Free Radicals Biology \& Medicine, 33, 220-235.

Reis, B., Martins, M., Barreto, B., Milhazes, N., Garrido, E.M., Silva, P., \& Garrido, J., Borges, F. (2010). Structure-property-activity relationship of phenolic acids and 
derivatives. Ptotocatechuic acid alkyl esters. Journal of Agricultural and Food Chemistry, 58, 6986-6993.

Sadler, M. (2003). Nutritional properties of edible fungi. Nutrition Bulletin, 28, 305308.

Scalbert, A., \& Williamson, G. (2000). Dietary intake and bioavailability of polyphenols. Journal of Nutrition, 130, 2073S-2085S.

Vaz, J.A., Heleno, S.A., Martins, A., Almeida, G.M., Vasconcelos, M.H., \& Ferreira, I.C.F.R. (2010). Wild mushrooms Clitocybe alexandri and Lepista inversa: In vitro In vitro antioxidant activity and growth inhibition of human tumour cell lines. Food and Chemical Toxicology, 48, 2881-2884.

Vaz, J.A., Almeida, G.M., Ferreira, I.C.F.R., Martins, A., \& Vasconcelos, M.H. (2012a). Clitocybe alexandri extract induces cell cycle arrest and apoptosis in a lung cancer cell line: identification of phenolic acids with cytotoxic potential. Food Chemistry, $132,482-486$.

Vaz, J.A., Ferreira, I.C.F.R., Tavares, C., Almeida, G.M., Martins, A., \& Vasconcelos, M.H. (2012b). Suillus collinitus methanolic extract increases p53 expression and causes cell cycle arrest and apoptosis in a breast cancer cell line. Food Chemistry, $135,596-602$.

Vaz, J.A., Barros, L., Martins, A., Morais, J.S., Vasconcelos, M.H., \& Ferreira, I.C.F.R. (2011). Phenolic profile of seventeen Portuguese wild mushrooms. LWT, 44, 343-346.

Zhang, Q., Raheem, K.S., Botting, N.P., Slawin, A.M.Z., Kay, C.D., \& O’Hagan, D. (2012). Flavonoid metabolism: the synthesis of phenolic glucuronides and sulfates as candidate metabolites for bioactivity studies of dietary flavonoid. Tetrahedron, 68, 4194-4201. 
<smiles>O=C(O)/C=C/c1ccc(O)cc1</smiles>

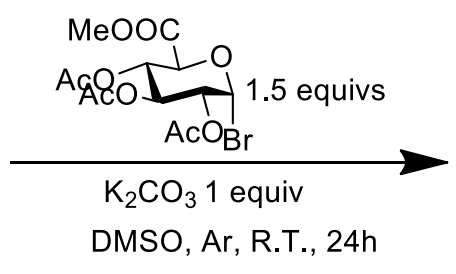<smiles>O=C(O)c1ccc(O)cc1</smiles>

HA<smiles>O=C(O)/C=C/c1ccccc1</smiles>
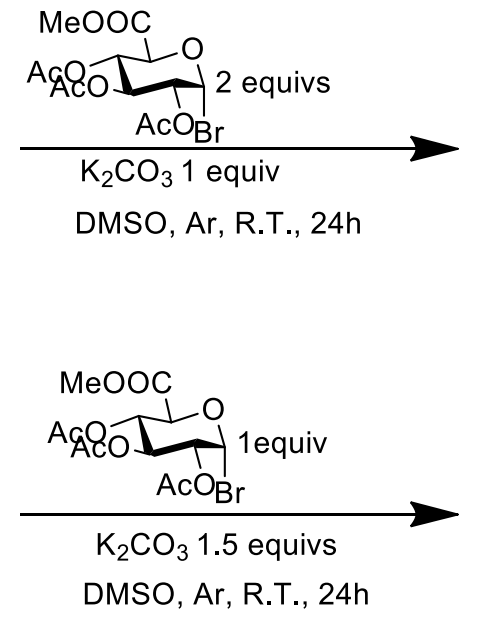

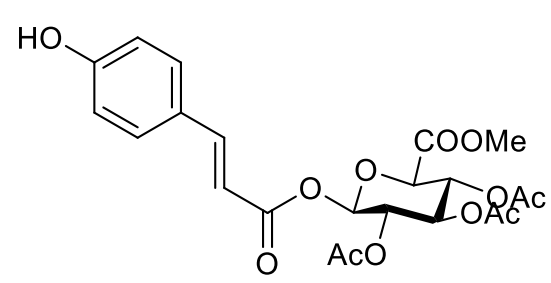

CoAGP

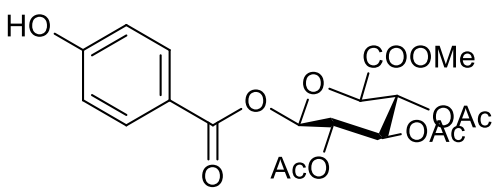

HAGP *

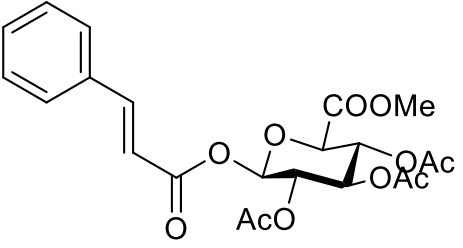

CAGP *

Scheme 1. Glucuronidation of $p$-coumaric, $p$-hydroxybenzoic and cinnamic acids. CoA- $p$-coumaric acid; CoAGP- $p$-coumaric acid glucuronide protected form; HA- $p$ hydroxybenzoic acid; HAGP- $p$-hydroxybenzoic acid glucuronide protected form; CAcinnamic acid; CAGP- cinnamic acid glucuronide protected form.

* Synthesis and structural characterization previously reported by the authors (Heleno et al., 2013). 

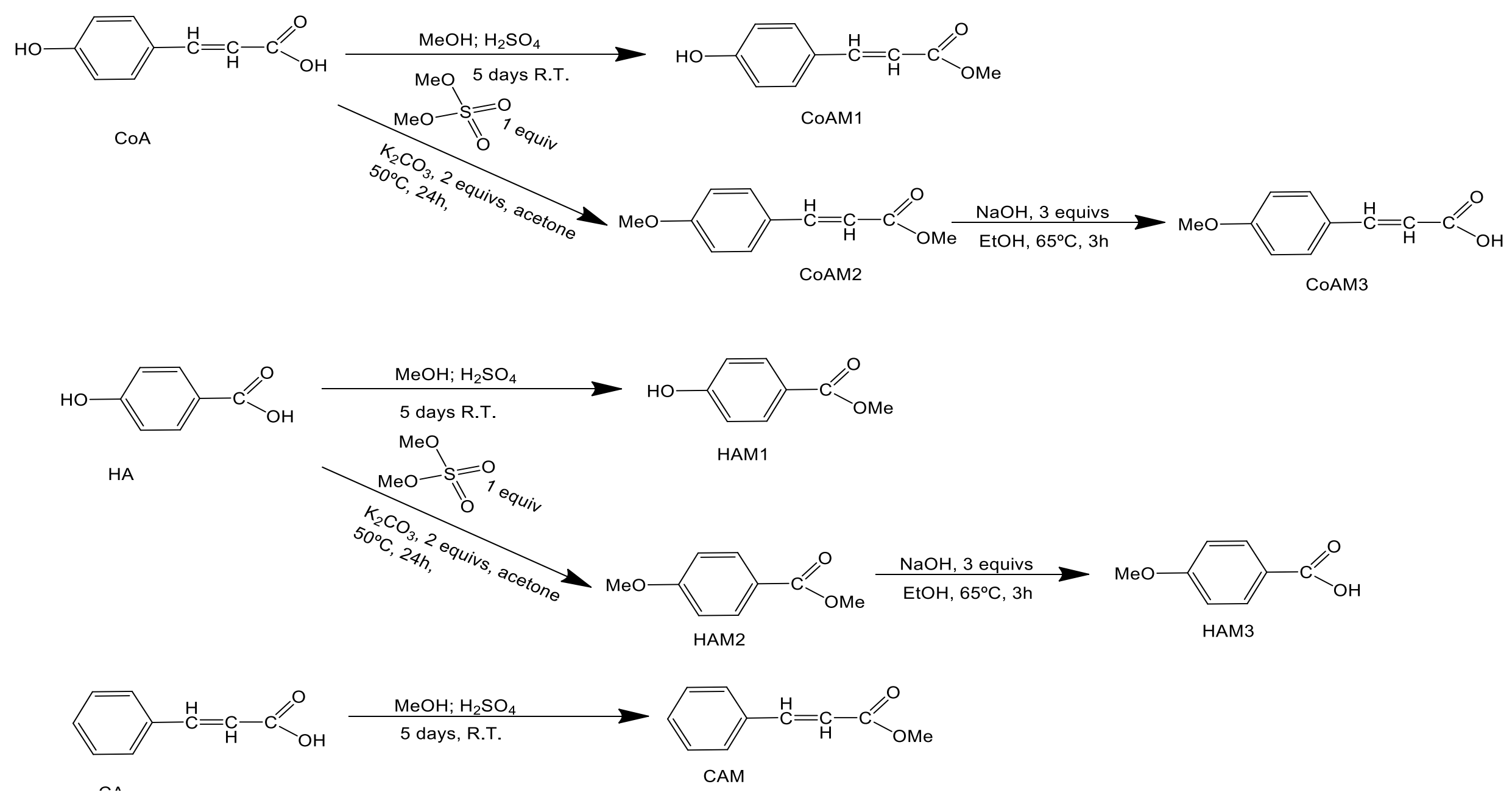
Table 1. Cytotoxicity of Coprinopsis atramentaria extract, organic acids and their synthesized methylated and glucuronide derivatives on various human tumor cell lines and in liver primary cells.

\begin{tabular}{|c|c|c|c|c|c|c|}
\hline & $\begin{array}{c}\text { MCF7 } \\
\text { (breast carcinoma) }\end{array}$ & $\begin{array}{c}\text { NCI-H460 } \\
\text { (non-small lung carcinoma) }\end{array}$ & $\begin{array}{c}\text { HCT15 } \\
\text { (colon carcinoma) }\end{array}$ & $\begin{array}{c}\text { HeLa } \\
\text { (cervical carcinoma) }\end{array}$ & $\begin{array}{c}\text { HepG2 } \\
\text { (hepatocellular carcinoma) }\end{array}$ & $\begin{array}{c}\text { PLP2 } \\
\text { (liver cells) }\end{array}$ \\
\hline Extract & $53.10 \pm 4.72$ & $15.13 \pm 1.35$ & $36.44 \pm 3.30$ & $>400$ & $>400$ & $>400$ \\
\hline CoA & $1152.84 \pm 58.65^{\mathrm{a}}$ & $1082.50 \pm 81.32^{\mathrm{a}}$ & $1177.46 \pm 32.54^{\mathrm{a}}$ & $>1250^{\mathrm{a}}$ & $>1250^{\mathrm{a}}$ & $>1250$ \\
\hline CoAGP & $334.62 \pm 8.20^{\mathrm{c}}$ & $384.21 \pm 16.85^{\mathrm{c}}$ & $284.99 \pm 2.39^{c}$ & $205.56 \pm 6.93^{c}$ & $134.35 \pm 14.68^{\mathrm{d}}$ & $>500^{*}$ \\
\hline CoAM1 & $295.42 \pm 6.41^{\mathrm{c}}$ & $282.75 \pm 8.44^{\mathrm{c}}$ & $274.94 \pm 12.72^{c}$ & $199.09 \pm 13.44^{\mathrm{c}}$ & $680.46 \pm 49.02^{b}$ & $>1250$ \\
\hline CoAM2 & $333.35 \pm 10.87^{\mathrm{c}}$ & $344.91 \pm 26.36^{\mathrm{c}}$ & $315.56 \pm 15.85^{\mathrm{c}}$ & $247.98 \pm 2.16^{\mathrm{b}}$ & $632.90 \pm 6.68^{c}$ & $>1250$ \\
\hline CoAM3 & $1013.97 \pm 36.21^{\mathrm{b}}$ & $915.79 \pm 81.70^{b}$ & $995.72 \pm 23.16^{\mathrm{b}}$ & $>1250^{\mathrm{a}}$ & $>1250^{\mathrm{a}}$ & $>1250$ \\
\hline HA & $>1250^{\mathrm{a}}$ & $>1250^{\mathrm{a}}$ & $>1250^{\mathrm{a}}$ & $>1250^{\mathrm{a}}$ & $>1250^{\mathrm{a}}$ & $>1250$ \\
\hline HAGP & $257.66 \pm 18.12^{\mathrm{c}}$ & $310.92 \pm 1.80^{c}$ & $195.49 \pm 0.75^{\mathrm{d}}$ & $192.39 \pm 7.72^{\mathrm{d}}$ & $57.78 \pm 5.65^{\mathrm{c}}$ & $>500^{*}$ \\
\hline HAM1 & $1140.70 \pm 4.51^{b}$ & $1060.69 \pm 70.13^{b}$ & $942.55 \pm 2.33^{\mathrm{c}}$ & $507.38 \pm 31.06^{\mathrm{c}}$ & $1169.42 \pm 64.37^{\mathrm{b}}$ & $>1250$ \\
\hline HAM2 & $>1250^{\mathrm{a}}$ & $>1250^{\mathrm{a}}$ & $1149.49 \pm 5.69^{b}$ & $850.73 \pm 14.75^{\mathrm{b}}$ & $>1250^{\mathrm{a}}$ & $>1250$ \\
\hline HAM3 & $>1250 \mathrm{a}$ & $>1250^{\mathrm{a}}$ & $>1250^{\mathrm{a}}$ & $>1250^{\mathrm{a}}$ & $>1250^{\mathrm{a}}$ & $>1250$ \\
\hline $\mathbf{C A}$ & $>1250^{\mathrm{a}}$ & $887.24 \pm 21.76^{\mathrm{b}}$ & $847.44 \pm 7.57^{b}$ & $1073.01 \pm 54.84^{\mathrm{b}}$ & $>1250^{\mathrm{a}}$ & $>1250$ \\
\hline CAGP & $306.40 \pm 16.69^{b}$ & $311.12 \pm 12.34^{\mathrm{c}}$ & $174.65 \pm 7.89^{c}$ & $121.42 \pm 2.79^{\mathrm{c}}$ & $289.92 \pm 11.25^{\mathrm{b}}$ & $>500^{*}$ \\
\hline CAM & $>1250^{\mathrm{a}}$ & $>1250^{\mathrm{a}}$ & $1195.99 \pm 3.87^{\mathrm{a}}$ & $>1250^{\mathrm{a}}$ & $>1250^{\mathrm{a}}$ & $>1250$ \\
\hline Ellipticine & $0.91 \pm 0.04$ & $1.42 \pm 0.00$ & $1.91 \pm 0.06$ & $1.14 \pm 0.21$ & $3.22 \pm 0.67$ & $2.06 \pm 0.03$ \\
\hline
\end{tabular}

The results are expressed as $\mathrm{GI}_{50}$ values $(\mu \mathrm{g} / \mathrm{ml}$ for extract and $\mu \mathrm{M}$ for compounds) corresponding to the extract/compound concentration, which inhibited $50 \%$ of cell growth. Results are from three independent experiments (performed in triplicate), and are expressed as mean \pm standard deviation (SD). Different letters in each column, and for each compound series, mean significant differences between $\mathrm{GI}_{50}$ values $(\mathrm{p}<0.05)$. ${ }^{*} \mathrm{Due}$ de low solubility of the compound, the maximum concentration tested was $500 \mu \mathrm{M}$. 